\title{
Desired Career Outcomes Among College Students: Differences by Gender and Intended Career Field
}

\author{
Florin D. Lung*, Geoff Potvinं, Gerhard Sonnert" and Philip M. Sadler \\ "Department of Physics \& Astronomy, Mississippi State University, Mississippi State, MS 39762 \\ 'Department of Engineering and Science Education, Clemson University, Clemson, SC 29634 \\ IScience Education Department, Harvard-Smithsonian Center for Astrophysics, Cambridge, MA 02138
}

\begin{abstract}
Using factor analysis we investigated the desired career outcomes of a large sample of college students. From fifteen original items, we extracted eight factors covering over $50 \%$ of the total variance. Some of these factors were associated with gender and/or intended career field. The "communal values" factor is positively associated with the female gender and a life sciences career interest, and negatively associated with an engineering career interest. Furthermore, the "innovator" factor is associated with the male gender and an interest in physical sciences and engineering careers. Another factor strongly associated with male gender is "career as means to social recognition." These results are in line with existing research pointing to different goals for males and females when choosing careers: Females are more oriented toward communal behavior and a connection with real life, whereas males are more attracted by social recognition and power.
\end{abstract}

Keywords: career choice, career outcome expectations, factor analysis.

PACS: 01.30.Cc, 01.40.Fk, 89.65.Cd, 89.65.Ef

\section{INTRODUCTION}

A current concern in science education is the underrepresentation of women in physical sciences. Recent statistics show that, in contrast with the more gender-balanced situation in biology or chemistry, the percentage of females among those who are awarded Bachelor degrees in physics is $21 \%$, and in engineering it is only $16 \%$ [1]. Causes range from societal, peer group, and family factors, to scientific community stereotypes about females in sciences [2]. Stereotypes, for instance, influence females' academic performance via the stereotype threat mechanism [3], or they become internalized by females themselves and heighten the females' focus on communal behavior and helping others [4]. Females thus are dissociated from career intentions in science fields unless the underrepresentation of females in fields such as physical sciences is explicitly discussed with them [5]. Even though strategies for countering the female stereotype threat have been developed [6-8], gender imbalances still linger in many science fields. One persistent cause for the observed gender disparities may be distinctions between what males and females desire to achieve in their careers. A communal goal orientation appears to be more salient among female than among male students. Females who see a utility value for everyday life in sciences were found to be more likely to pursue their study in these fields $[9,10$, 11]. In this case - and we expect such an association to exist for both genders - career goal orientations also appear tied to intended career fields.
In the current work, we explore the hypothesis that desired career outcomes differ by gender and that they differ by intended career field. From survey data, we identify underlying factors in students' desired career outcomes and establish their links with gender and career interest in sciences. The results should be of interest for those teaching engineering and life sciences students, in particular physics instructors, as well as for science education researchers.

\section{SAMPLE AND METHOD}

The study is based on the 7505 student responses to the PRiSE survey (NSF Award No. 0624444), a nationally representative sample for college students enrolled in introductory English courses. Students' career interests in physical science, life science, and engineering careers were recorded as 6-point Likertlike scales ( $1=$ not at all likely; $6=$ extremely likely). Students' desired career outcomes expectations were also recorded on 6-point scales $(1=$ not at all important for future career satisfaction; 6=very important for future career satisfaction). There were 15 original items, on which we performed a factor analysis using the promax method. Eight factors were extracted [12]. We then analyzed the correlations these factors have with gender and with student career interest in physical sciences, life sciences, and engineering. We hypothesized that student interest in physical science and engineering careers is associated with typical male 
desired career outcomes, while interest in life sciences correlates with typical female desired career outcomes.

\section{METHOD AND RESULTS}

The set of 15 items relating to desired career outcomes is shown in Table I. The set of variables for analysis was first treated for missing data in $\mathrm{R}$, using the Amelia package. The resulting imputed dataset was then subjected to a promax factor analysis, which yielded eight non-orthogonal factors, the cumulative explained variance being 0.54 . The choice of eight factors has two reasons. First, this is the number of factors with eigenvalues higher than the mean shown in Figure 1; second, it represented the best compromise between analyses which yielded factor loadings larger than 1 typical for over-extracted factor cases $(n=8)$ and analyses with fewer factors covering a smaller percentage of the total variance.

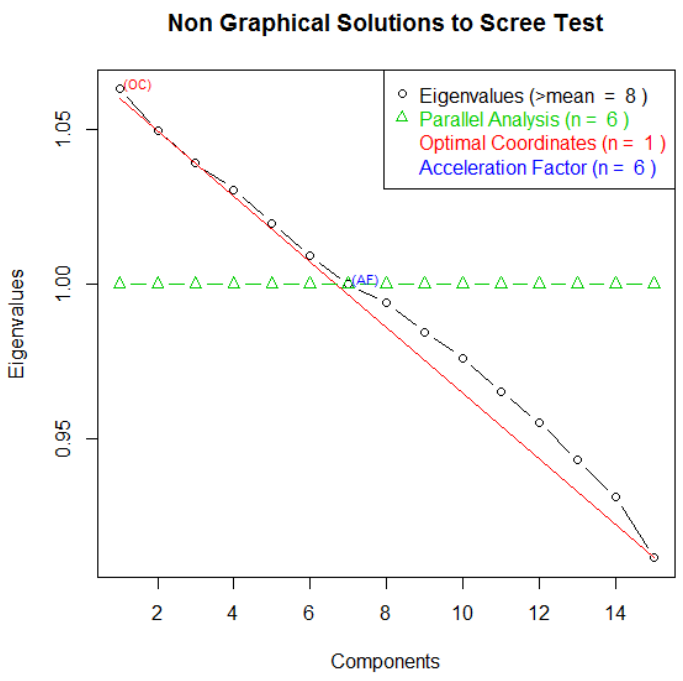

FIGURE 1. Scree test for the number of extracted factors

To aid interpretation of these factors, we also considered the correlation coefficients between them. Table II shows the correlations of the eight factors with the original items, as well as with the other factors (only the highest correlation coefficients are shown).
TABLE I. The set of survey items relating to desired career outcomes. The items are measured on a Likert-like scale from 1 (not important) to 6 (very important)

\begin{tabular}{l|c}
\hline Item Name & Importance of item for career choice \\
\hline q2money & Money \\
\hline q2fame & Fame \\
\hline q2help & Helping others \\
\hline q2lead & Work security \\
\hline q2secure & Working with people \\
\hline q2peopl & Inventing \\
\hline q2invent & Time for family \\
\hline q2devel & Time for self \\
\hline q2famly & Making own decisions \\
\hline q2myself & Having an easy job \\
\hline q2ownd & Having an exciting job \\
\hline q2easyj & Using one's own talent \\
\hline q2talent & Having job opportunities \\
\hline q2jobop &
\end{tabular}

TABLE II. The eight factors extracted from desired career outcomes

\begin{tabular}{|c|c|}
\hline $\begin{array}{l}\text { Factor } \\
\text { (variance } \\
\text { explained) }\end{array}$ & $\begin{array}{l}\text { Correlation with initial variables and the } \\
\text { other factors }\end{array}$ \\
\hline $\begin{array}{ll}\text { Factor } & 1 \\
(0.10) & \end{array}$ & $\begin{array}{l}\text { Using one's own talent }(\mathrm{r}=0.92) \text {, Having an } \\
\text { exciting job }(\mathrm{r}=0.57) \\
\text { Factor } 6(\mathrm{r}=0.59) \text {, Factor } 2(\mathrm{r}=0.45) \text {, Factor } \\
8(\mathrm{r}=-0.42), \text { Factor } 5(\mathrm{r}=0.41)\end{array}$ \\
\hline $\begin{array}{l}\text { Factor } \\
(0.09)\end{array}$ & $\begin{array}{l}\text { Having time for self }(\mathrm{r}=0.90) \text {, Having time } \\
\text { for family }(\mathrm{r}=0.52) \\
\text { Factor } 6(\mathrm{r}=0.62) \text {, Factor } 5(\mathrm{r}=0.54) \text {, Factor } \\
4 \quad(\mathrm{r}=0.47) \text {, Factor } 1 \quad(\mathrm{r}=0.45) \text {, Factor } 7 \\
(\mathrm{r}=0.44)\end{array}$ \\
\hline $\begin{array}{l}\text { Factor } \\
(0.08)\end{array}$ & $\begin{array}{l}\text { Work security }(r=0.74) \text {, Money }(r=0.46) \text {, } \\
\text { Having job opportunities }(r=0.44)\end{array}$ \\
\hline $\begin{array}{l}\text { Factor } \\
(0.08)\end{array}$ & $\begin{array}{l}\text { Helping others }(\mathrm{r}=0.88) \text {, Working with } \\
\text { people }(0.51) \\
\text { Factor } 2(\mathrm{r}=0.47), \text { Factor } 7(\mathrm{r}=0.45)\end{array}$ \\
\hline $\begin{array}{l}\text { Factor } \\
(0.07)\end{array}$ & $\begin{array}{l}\text { Fame }(r=0.70) \text {, Leading others }(r=0.51) \\
\text { Factor } 6(r=0.56) \text {, Factor } 2(r=0.54) \text {, Factor } \\
1(r=0.41)\end{array}$ \\
\hline $\begin{array}{l}\text { Factor } \\
(0.05)\end{array}$ & $\begin{array}{l}\text { Inventing }(\mathrm{r}=0.81), \quad \text { Developing } \\
\text { knowledge }(\mathrm{r}=0.34) \\
\text { Factor } 2(\mathrm{r}=0.62) \text {, Factor } 1(\mathrm{r}=0.59) \text {, Factor } \\
5(\mathrm{r}=0.56) \text {, Factor } 7(\mathrm{r}=0.48)\end{array}$ \\
\hline $\begin{array}{l}\text { Factor } \\
(0.03)\end{array}$ & $\begin{array}{l}\text { Having an easy job }(\mathrm{r}=0.63) \\
\text { Factor } 4 \text { and Factor } 6(\mathrm{r}=0.48) \text {, Factor } 8 \\
(\mathrm{r}=-0.48)\end{array}$ \\
\hline $\begin{array}{l}\text { Factor } \\
(0.03)\end{array}$ & $\begin{array}{l}\text { Money }(0.62) \\
\text { Factor } 7(\mathrm{r}=-0.48)\end{array}$ \\
\hline
\end{tabular}

Table III suggests a possible interpretation for these eight factors extracted. The most important, covering $10 \%$ of the total variance is enthusiasm, or passion, for work, associated with using talent and having an exciting job. The second factor, career as means for pursuing private interests, is characterized by a preference for having more time for self and family. 
The third factor, covering $8 \%$ of the total variance, is the career seen as a contract, where the effort is rewarded by stability and money.

TABLE III. Interpretation of the eight factors extracted and their correlations with gender status. A negative correlation coefficient means female students consider the factor as more important, in comparison with male students

\begin{tabular}{l|c}
\hline \multicolumn{1}{c|}{ Factor } & $\begin{array}{c}\text { Correlation with } \\
\text { gender }\end{array}$ \\
\hline 1. Enthusiasm for work & -0.03 \\
\hline $\begin{array}{l}\text { 2. Career as means to sustain } \\
\text { personal interests }\end{array}$ & 0.00 \\
\hline $\begin{array}{l}\text { 3. Career offering a secure } \\
\text { position ensuring prosperity }\end{array}$ & -0.03 \\
\hline 4. Communal values & $\mathbf{- 0 . 2 5}$ \\
\hline $\begin{array}{l}\text { 5. Career as a means to social } \\
\text { recognition }\end{array}$ & 0.11 \\
\hline 6. Innovator & $\mathbf{0 . 2 3}$ \\
\hline 7. Socializer & 0.02 \\
\hline $\begin{array}{l}\text { 8. Making money by working } \\
\text { hard }\end{array}$ & -0.01 \\
\hline
\end{tabular}

Among these three most important factors, none has a clear gender pattern, as the bi-serial correlation coefficients (used whenever one of the variables is dichotomous $)$ with student gender $(0=$ female, $1=$ male $)$ in Table III show. Owing to the construction of gender variable, the negative correlation coefficients with gender indicate an association of the respective factor with female students, whereas a positive correlation coefficient indicates that the respective factor is associated with the male students.

The first factor, in the order of importance, having a notable association with gender is factor 4, named "communal values," which is associated with females $(-0.25$, medium effect size). The next two factors are both associated with males, the "career as means to social recognition" and the "innovator" (the latter covering $5 \%$; the former, $7 \%$ of the total variance). The last two factors, "socializer" and "making money by working hard", again do not have a notable gender association.

Finally, we investigated the correlation between the factors and student interest in science careers. The Spearman correlation coefficients are shown in Table IV.

For physical science career interest, the by far strongest correlation is with the "innovator" factor (0.21, a medium-small correlation effect size). An even stronger correlation for "innovator" was found with engineering career interest $(0.37$, medium-large effect size). In that case, another notable (negative) correlation exists with the factor "communal values" (-0.17, medium-small). As expected, engineering career interest has a strong correlation with gender, in the direction of male students. On the other hand, the factor that has the strongest correlation with life sciences career interest is exactly the "communal values" factor, while the correlation of life sciences career interest with female gender is also mediumstrong, as one might expect from women's focus on communal values. The other correlations, though most are significant due to the large sample size, cover a much smaller part of the science career interest picture.

TABLE IV. Spearman correlation coefficients between science career interests and career outcome expectation factors, and gender

\begin{tabular}{|c|c|c|c|}
\hline $\begin{array}{l}\text { Factor/ science } \\
\text { career interest }\end{array}$ & $\begin{array}{l}\text { Physical } \\
\text { sciences }\end{array}$ & $\begin{array}{c}\text { Life } \\
\text { sciences }\end{array}$ & Engineering \\
\hline $\begin{array}{l}1 \text { Enthusiasm } \\
\text { for work }\end{array}$ & -0.06 & -0.05 & -0.08 \\
\hline $\begin{array}{l}2 \text { Career as } \\
\text { means to sustain } \\
\text { personal } \\
\text { interests }\end{array}$ & -0.07 & -0.06 & -0.04 \\
\hline $\begin{array}{l}3 \quad \text { Career } \\
\text { offering a secure } \\
\text { position } \\
\text { ensuring } \\
\text { prosperity }\end{array}$ & 0.06 & 0.05 & 0.08 \\
\hline $\begin{array}{l}4 \text { Communal } \\
\text { values }\end{array}$ & 0.05 & 0.17 & -0.17 \\
\hline $\begin{array}{l}5 \text { Career as a } \\
\text { means to social } \\
\text { recognition }\end{array}$ & -0.05 & -0.06 & 0.02 \\
\hline 6 Innovator & 0.21 & 0.08 & 0.37 \\
\hline 7 Socializer & -0.04 & -0.03 & -0.01 \\
\hline $\begin{array}{l}8 \text { Making } \\
\text { money by } \\
\text { working hard }\end{array}$ & 0.04 & 0.04 & 0.05 \\
\hline Gender & 0.05 & -0.14 & 0.37 \\
\hline
\end{tabular}

\section{DISCUSSION AND FUTURE WORK}

Our results are in line with the female communal values paradigm, in that the "communal values" factor correlates highly with female gender status, and also because it has a high correlation with the life science career interest. While the correlation between gender and physical science career interest is lower than we expected, we have found that there are two distinct male desired career outcomes, innovation, which is important for physical sciences and engineering career interests, and social recognition, which is not specific to a particular field investigated. An interesting result is that, in addition to a strong association with the innovation factor, the engineering career interest is also negatively correlated with the communal values factor, which is exactly the factor that attracts females to the 
life sciences. Here it appears to repel females from the engineering field.

This is a preliminary result which can be improved by building an inferential model (e.g., path analysis). Moreover, a subsequent confirmatory factor analysis should give a more precise picture of the links between the initial items describing desired career outcomes and their underlying factors. Finally, potential interaction effects between gender and career interest in predicting desired career outcomes should be examined.

Two possible avenues for subsequent research emerge from our results. First, the contrasting correlates of career interests in life sciences and in engineering beg the question whether implementing, in engineering curricula, more collaborative work and opportunities to help others would have the effect of improving the female representation in engineering careers. The answer to this question may be informative for the teaching of engineering and the research in engineering education. Second, the fact that our data show a smaller correlation of the "innovator" factor with career interest in life sciences than with career interest in the physical sciences and engineering, leads us to hypothesize that students opting for the life sciences career are more inclined to pursue a career of applied science in the interest of helping others, than toward making scientific innovations.

The findings presented here should provide college physics instructors with a rationale for using communal-centered topics and activities when teaching life science majors. Or, if the instructors' goals are to facilitate females' access to physical sciences and engineering, they should include such activities in classroom activities.

\section{REFERENCES}

1. National Science Board (2012). Science and engineering indicators 2012. Arlington, VA: National Science Foundation

2. Tindall, T. and Hamil, B. (2004). Gender disparity in science education: the causes, consequences, and solutions. Education, 125 (2), 282-295.

3. Steele, C. M. (1997). A threat in the air. How stereotypes shape intellectual identity and performance, American Psychologist, 52(6), 613-629

4. Eagly, A. H., Wood, W., Diekman, A. B. (2000). Social role theory of sex differences and similarities: a current appraisal, in Eckes, T., Trautner, H. M. (eds.), The developmental social psychology of gender, Mahwah, NY, Lawrence Erlbaum Publishers

5. Hazari, Z., Potvin, G.. Lock, R. M., Lung, F., Sonnert, G., and Sadler, P. M. (2013). Factors that affect the physical science career interest of female students: Testing five common hypotheses, Physical Review Special Topics - Physics Education Review (accepted Aug 20 2013)
6. Dar-Nimrod, I., Heine, S. J. (2006). Exposure to scientific theories affects women's math performance, Science 314 , 435

7. Miyake, A., Kost-Smith, L. E., Finkelstein, N. D., Pollock, S. J., Cohen, G. L., \& Ito, T. A. (2010). Reducing the gender achievement gap in college science: a classroom study of values affirmations, Science, 330, 1234(2010).

8. Stout, J. G., Dasgupta, N., Hunsiger, M., \& McManus, M. (2011). STEMing the tide: using ingroup experts to inoculate women's self-concepts in science, technology, engineering, and mathematics (STEM), Journal of Personality and Social Psychology, 100 (2), pp. 255-270 (2011)

9. Carlone, H. and Johnson, A. (2007) Understanding the science experiences of women of color: Science identity as an analytic lens. Journal of Research in Science Teaching 44(1187-1218).

10. Stout, J. G., Ito, T. A., Finkelstein, N. D., \& Pollock, S. J. (2012). How a gender gap in belonging contributes to the gender gap in physics participation, 2012 Physics Education Research Conference Proceedings

11. Hulleman, C. S., Godes, O., Hendricks, B. L., and Harackiewicz, J. M. (2010). Enhancing interest and performance with a utility value intervention, Journal of Educational Psychology 102 (4), 880-895

12. Tabachnick, B. G., Fidell, L. S. (2007). Using multivariate statistics, Boston, MA, Pearson 